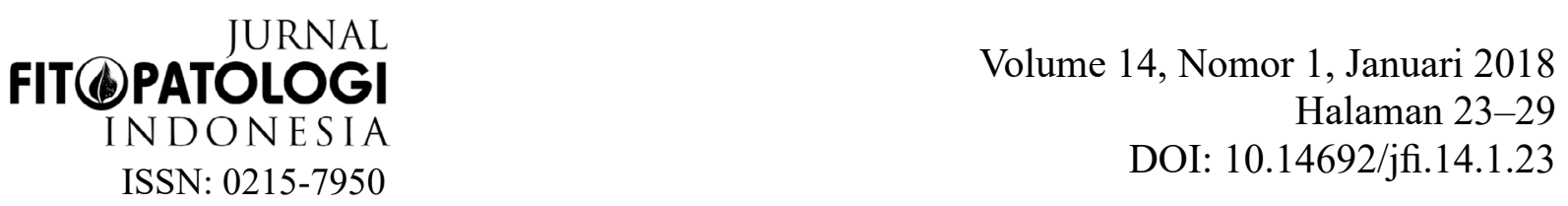

\title{
Aktivitas Antagonis Bakteri Endofit Asal Mangrove terhadap Ralstonia solanacearum dan Meloidogyne spp.
}

\author{
Antagonistic activities of Mangrove Endophytic Bacteria Against \\ Ralstonia solanacearum and Meloidogyne spp.
}

\author{
Muhammad Firdaus Oktafiyanto, Abdul Munif*, Kikin Hamzah Mutaqin \\ Institut Pertanian Bogor, Bogor 16680
}

\begin{abstract}
ABSTRAK
Penyakit utama pada tanaman tomat yang disebabkan oleh bakteri layu (Ralstonia solanacearum) dan nematoda puru akar (Meloidogyne spp.) dapat menimbulkan kerugian yang besar sehingga perlu dikendalikan. Saat ini, pengendalian dengan bakteri endofit telah banyak dikembangkan untuk menekan pertumbuhan patogen. Penelitian ini bertujuan memperoleh bakteri endofit dari mangrove yang dapat menekan pertumbuhan nematoda puru akar dan bakteri layu. Sebanyak 843 isolat bakteri endofit berhasil diisolasi dari mangrove, selanjutnya dilakukan uji keamanan hayati. Hasil pengujian menunjukkan 403 galur bakteri endofit memberi hasil negatif dalam uji hipersensitif dan hemolitik. Hasil pengujian in vitro menunjukkan 19 galurmampu menekan pertumbuhan $R$. solanacearum dan mematikan Meloidogyne. Sebanyak 14 galur mampu menghasilkan enzim protease dan 11 galur mampu menghasilkan kitinase. Penelitian ini memberikan informasi bakteri endofit dari mangrove yang memiliki potensi sebagai agens hayati.
\end{abstract}

Kata kunci: nematoda puru akar, penyakit layu, uji keamanan hayati, uji hemolitik, uji hipersensitif

\begin{abstract}
The main diseases of tomato caused by wilt bacteria (Ralstonia solanacearum) and root knot nematodes (Meloidogyne spp.) may cause significant yield losses and need to be managed. Recently, biocontrol approach especially using endophytic bacteria has been developed to control plant pathogens. This research was aimed to obtain endophytic bacteria from 2 species of mangrove, which effectively controlled root knot nematode and wilt bacteria. A total of 843 endophytic bacteria were successfully isolated from 2 species of mangroves. The bacteria isolates were further subjected for biosafety assay. The results of the test showed that 403 endophytic bacteria gave negative reaction in hypersensitive and hemolytic tests. Furthermore, 19 isolates effectively suppressed the growth $R$ solanacearum and killed Meloidogyne in in vitro test. Physiological test showed that 14 and 11 isolates of the bacteria were able to produce protease and chitinase, respectively. This research provides a new information that endophytic bacteria from mangrove has a potency as a biocontrol agents.
\end{abstract}

Key words: biosafety assay, hemolytic test, hypersensitive test, root knot nematode, wilt disease

*Alamat penulis korespondensi: Departemen Proteksi Tanaman, Fakultas Pertanian, Institut Pertanian Bogor, Jalan Kamper, Kampus IPB Dramaga, Bogor 16680

Tel: 0251-8629364, Faks: 0251-8629362, Surel: munif73@gmail.com 


\section{PENDAHULUAN}

Produksi tomat mengalami penurunan hingga 1.62 ton $\mathrm{ha}^{-1}$ pada tahun 2013-2015, sementara luas lahan pada tahun yang sama meningkat sebesar 2221 ha. (Kementan 2015). Tanaman tomat merupakan inang dari Ralstonia solanacearum dan Meloidogyne spp. yang menyebabkan penurunan produksi sangat besar yang dapat disebabkan oleh infeksi satu maupun beberapa patogen secara bersamaan. Gejala layu pada tanaman tomat di antaranya disebabkan oleh bakteri $R$. solanacearum, dan nematoda Meloidogyne spp (Sudana dan Lotrini 2005).

Agens hayati sebagai pengendali patogen saat ini banyak dikembangkan dan salah satunya ialah bakteri endofit. Hallmann et al. (1997) menyatakan bahwa bakteri endofit mampu mengolonisasi jaringan tanaman tanpa menimbulkan penyakit. Bakteri endofit dilaporkan dapat mengendalikan penyebab layu yang disebabkan $R$. solanacearum dan meningkatkan pertumbuhan tanaman terung (Ramesh et al. 2009).

Tanaman mangrove merupakan tanaman halofit, yaitu tanaman yang dapat hidup dalam keadaan $\mathrm{NaCl}$ tinggi. Bakteri endofit asal tanaman mangrove di India dilaporkan sebagai penghasil antibiotik, enzim pektinase, protease, kitinase, lipase, penyedia fosfat, penghasil hormon auksin, dan mampu memfiksasi nitrogen (Gayathri dan Muralikrisan 2013). Melihat potensi bakteri endofit dan belum banyak bakteri endofit dari mangrove di Indonesia maka penelitian ini bertujuan memperoleh bakteri endofit dari mangrove untuk menekan $R$. solanacearum dan Meloidogyne spp.

\section{BAHAN DAN METODE}

\section{Isolasi Bakteri Endofit}

Tanaman mangrove diambil dari 4 lokasi, yaitu Desa Karangsong-Indramayu, Baros Bantul-Yogyakarta, Taman Wisata Alam Angke Kapuk-Jakarta dan Taman Nasional Alas Purwo Blok Bedul-Banyuwangi. Bakteri endofit diisolasi dari perakaran tanaman
Avicennia dan Rhizopora mengikuti metode Hallmann et al. (1997). Akar udara tanaman mangrove disterilisasi permukaannya dengan $\mathrm{NaOCl} 2 \%$ dan alkohol 70\%, kemudian akar digores pada medium kontrol untuk melihat keberhasilan sterilisasi permukaan. Akar dimaserasi, suspensi bakteri diremajakan pada medium tryptic soya agar (TSA), nutrient agar (NA) dan medium King's B masingmasing dengan konsentrasi $20 \%$ dan $50 \%$.

\section{Uji Keamanan Hayati}

Uji hemolisis dilakukan dengan menggores bakteri pada medium agar-agar darah. Terbentuknya zona bening dan keruh pada medium menandakan bakteri bereaksi positif karena dapat mendegradasi komponen sel darah merah pada medium.

Uji hipersensitif dilakukan dengan menyuntikkan $1 \mathrm{~mL}$ suspensi bakteri endofit dalam tryptic soy broth (TSB) berumur 24 jam di bagian bawah daun tembakau dan selanjutnya diinkubasi selama 24-48 jam. Pengamatan dilakukan terhadap kemunculan bercak nekrosis yang menandakan reaksi positif hipersensitif.

\section{Uji Aktivitas Antagonis Bakteri Endofit terhadap $R$. solanacearum dan Meloidogyne spp. Secara in Vitro}

Bakteri endofi di uji aktivitas antibakterinya terhadap $R$. solanacearum. Galur $R$. solanacearum berasal dari tanaman tomat sakit di daerah Ciawi-Bogor. Sebanyak $50 \mu \mathrm{L}$ suspensi $R$. solanacearum disebar pada medium NA. Selanjutnya kertas saring dengan diameter $0.5 \mathrm{~cm}$ diletakkan di atas medium. Kertas saring di tetesi $3 \mu \mathrm{L}$ suspensi bakteri endofit asal tanaman mangrove dan sebagai kontrol kertas saring ditetesi $3 \mu \mathrm{L}$ medium nutrient broth (NB). Aktivitas anti-bakteri diamati pada 24-48 jam setelah perlakuan. Terbentuknya zona bening di sekeliling kertas saring menunjukkan kemampuan bakteri endofit menghasikan antibiotik. Lebarnya zona bening diukur untuk mengetahui zona antibiotik yang dihasilkan.

Pengujian ini disusun dalam rancangan acak lengkap dengan 2 ulangan untuk setiap 
pengujian. Data yang diperoleh dianalisis menggunakan $\alpha 0.05$ dan dilanjutkan dengan uji Duncan pada $\alpha 0.05$.

Uji Aktivitas Nematisidal Kultur Filtrat Bakteri Endofit terhadap Meloidogyne spp.

Meloidogyne spp. diisolasi dari tanaman tomat yang bergejala puru di daerah Pasir Sarongge-Cipanas. Bakteri endofit dibiakkan pada $15 \mathrm{~mL}$ medium TSB dan diinkubasi selama 48 jam pada alat pengocok dengan kecepatan $300 \mathrm{rpm}$. Selanjutnya, suspensi bakteri endofit disentrifugasi dengan kecepatan $13000 \mathrm{rpm}$ selama 5 menit. Sebanyak $5 \mathrm{~mL}$ biakan bakteri endofit dimasukkan ke dalam cawan sirakus yang berisi 50 ekor Meloidogyne spp. juvenil 2, sedangkan untuk kontrol sebanyak $5 \mathrm{~mL}$ medium TSB diteteskan ke Meloidogyne spp. Pengamatan dilakukan terhadap mortalitas nematoda setelah 12 jam dan 24 jam menggunakan mikroskop.

Karakterisasi Sifat Fisiologis Bakteri Endofit

Kemampuan bakteri endofit menghasilkan protease dilakukan pada medium skim milk agar (SMA). Bakteri yang mampu memproduksi protease akan membentuk zona bening di sekitar koloni.

Kemampuan bakteri endofit menghasilkan kitinase diuji menggunakan medium agar-agar kitin. Zona bening akan terbentuk di sekitar koloni apabila terdapat bakteri yang mampu memproduksi enzim kitinase.

\section{HASIL}

Bakteri endofit dari perakaran tumbuhan mangrove ialah sebanyak 843 isolat; 206 isolat berasal dari Karangsong Indramayu; 229 isolat dari Baros Bantul, Yogyakarta; 208 isolat dari Angke Kapuk Jakarta; dan 200 isolat dari hutan mangrove Taman Nasional Alas Purwo Blok Bedul Banyuwangi. Isolatisolat tersebut selanjutnya diremajakan lagi pada medium TSA. Sebanyak 769 isolat bakteri endofit dapat dikultur ulang. Hasil uji hemolisis menunjukkan sebanyak 227 isolat (29.5\%) bakteri bereaksi positif dengan mengubah warna medium (Gambar 1). Sebanyak 139 isolat $(25.6 \%)$ bereaksi positif dan menyebabkan nekrosis pada daun tembakau setelah 48 jam (Gambar 2). Hasil pengujian hemolisis dan hipersensitif menunjukkan 403 isolat bakteri yang aman digunakan untuk uji lanjut.

Sebanyak 403 isolat yang memiliki hasil negatif hemolisis dan hipersensitif diuji kemampuannya dalam menekan pertumbuhan $R$. solanacearum pada medium NA. Pengujian dilakukan melalui dua tahap, yaitu preeliminasi dan tingkat antagonisme bakteri. Pre-eliminasi dilakukan untuk mengeliminasi bakteri yang tidak memiliki sifat antibiosis terhadap $R$. solanacearum. Hasil pengujian menunjukkan terdapat 19 isolat bakteri endofit memiliki daya antagonis yang stabil dengan membentuk zona bening di sekitar kertas saring. Sebanyak 8 isolat yang memiliki zona bening yang tertinggi, yaitu KAN5-8 (1.42 mm), YRK2-4 (1.42), YRK5-3 (1.25mm) YRK5-3 (2.00mm), BAT5-12 (1.50mm), BRN5-4 (1.75mm), BAT2-2 (2.33 $\mathrm{mm})$, BRK5-4 (1.75mm), dan JAT5-1 $(1.25 \mathrm{~mm})$ (Tabel 1).

Sebanyak 19 isolat bakteri yang menunjukkan sifat antagonis terhadap $R$. solanacearum diuji dalam menekan nematoda puru akar (Meloidogyne spp) secara in vitro. Hasil pengamatan pada 12 dan 24 jam menunjukkan bahwa semua isolat bakteri endofit yang diuji mampu membunuh Meloidogyne spp. juvenil 2. Nilai penekanan tertinggi ditunjukkan setelah pengamatan 24 jam, 4 isolat yang memiliki tingkat mortalitas tertinggi ialah: JRK5-4 (95.7\%), JRN5-1 (87.68), BAT2-12 (85.63) dan BAT2-2 (87.53\%) (Tabel 1). Isolat yang memiliki aktivitas antagonis terhadap $R$. solanacearum dan Meloidogyne spp. diuji kemampuannya dalam uji fisiologis. Sebanyak 14 isolat bakteri endofit menghasilkan protease yang ditunjukkan dengan munculnya zona bening di sekitar bakteri (Gambar 3). Sebanyak 11 isolat bakteri menghasilkan enzim kitinase yang ditunjukkan dengan zona bening di sekitar bakteri (Gambar 3) (Tabel 2). 


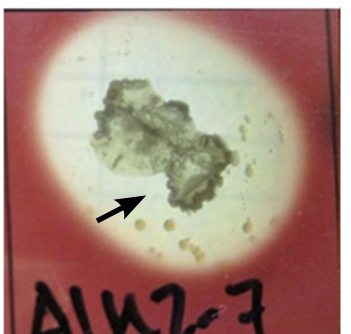

$\mathrm{a}$

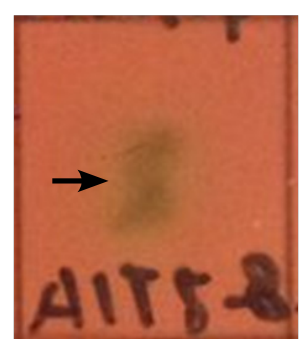

$\mathrm{b}$

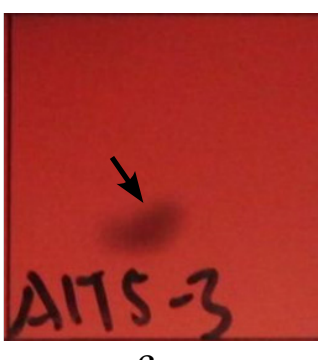

C

Gambar 1 Bakteri endofit pada medium agar-agar darah. a, $\beta$-hemolisis membentuk zona bening di sekitar koloni bakteri; $b, \alpha$-hemolisis membentuk zona gelap berwarna kehijauan atau kecoklatan; dan c, $\gamma$-hemolisis tidak terjadi perubahan pada medium.

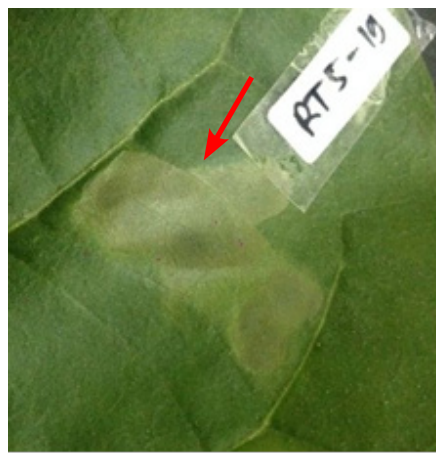

a

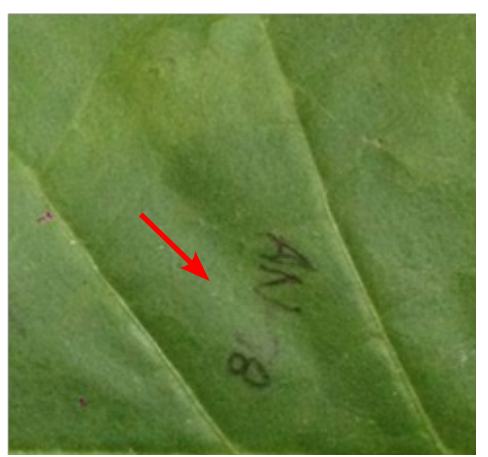

b

Gambar 2 Reaksi hipersensitif bakteri endofit pada bagian bawah daun tembakau. a, nekrosis; dan $\mathrm{b}$, kontrol tidak terbentuk nekrosis.

Tabel 1 Pengujian 19 isolat bakteri endofit terpilih terhadap Ralstonia solanacearum dan Meloidogyne spp.

\begin{tabular}{lllc}
\hline \multirow{2}{*}{ Isolat bakteri } & $\begin{array}{c}\text { Lebar zona bening terhadap R. solanacearum } \\
(\mathrm{mm})\end{array}$ & \multicolumn{2}{c}{ Mortalitas nematoda (\%) } \\
\cline { 3 - 4 } & $0.00 \mathrm{a}$ & $2.4 \mathrm{a}$ & $24 \mathrm{Jam}$ \\
\hline Kontrol & $1.42 \mathrm{bcd}$ & $39.2 \mathrm{bcdef}$ & $58.2 \mathrm{ac}$ \\
KAN5-8 & $1.00 \mathrm{abc}$ & $35.4 \mathrm{bcdef}$ & $56.0 \mathrm{bc}$ \\
KAK2-8 & $1.17 \mathrm{bc}$ & $44.0 \mathrm{efg}$ & $59.8 \mathrm{bc}$ \\
KAK2-4 & $1.08 \mathrm{abc}$ & $27.3 \mathrm{~b}$ & $59.2 \mathrm{bc}$ \\
KAT5-1 & $1.25 \mathrm{bcd}$ & $34.2 \mathrm{bcdef}$ & $79.7 \mathrm{fg}$ \\
YRN5-3 & $1.42 \mathrm{bcd}$ & $35.6 \mathrm{bcdef}$ & $52.9 \mathrm{~b}$ \\
YRK2-4 & $2.00 \mathrm{~cd}$ & $32.0 \mathrm{bcde}$ & $72.8 \mathrm{def}$ \\
YRK5-3 & $0.83 \mathrm{ab}$ & $43.4 \mathrm{defg}$ & $81.0 \mathrm{fg}$ \\
YRT5-10 & $1.50 \mathrm{bcd}$ & $40.8 \mathrm{cdef}$ & $85.6 \mathrm{gh}$ \\
BAT5-12 & $2.33 \mathrm{~d}$ & $54.1 \mathrm{~g}$ & $87.5 \mathrm{gh}$ \\
BAT2-2 & $1.17 \mathrm{bc}$ & $31.2 \mathrm{bc}$ & $67.5 \mathrm{cde}$ \\
BAT2-7 & $45.3 \mathrm{fg}$ & $72.1 \mathrm{def}$ \\
BAT-14 & $1.00 \mathrm{abc}$ & $34.2 \mathrm{bcdef}$ & $57.0 \mathrm{bc}$ \\
BRN2-2 & $0.92 \mathrm{abc}$ & $38.1 \mathrm{bcdef}$ & $77.0 \mathrm{efg}$ \\
BRN5-2 & $1.42 \mathrm{bcd}$ & $31.4 \mathrm{bcd}$ & $72.5 \mathrm{def}$ \\
BRK5-4 & $1.75 \mathrm{bcd}$ & $38.7 \mathrm{bcdef}$ & $79.3 \mathrm{efg}$ \\
JAT5-1 & $1.25 \mathrm{bcd}$ & $45.6 \mathrm{fg}$ & $61.6 \mathrm{~cd}$ \\
JAT5-2 & $1.08 \mathrm{abc}$ & $28.2 \mathrm{~b}$ & $87.6 \mathrm{gh}$ \\
JRN5-1 & $1.08 \mathrm{abc}$ & $38.9 \mathrm{bcdef}$ & $95.7 \mathrm{~h}$ \\
JRK5-4 & $0.83 \mathrm{ab}$ & &
\end{tabular}

Angka selajur yang diikuti huruf yang sama menunjukkan tidak berbeda nyata menurut uji Duncan pada $\alpha 0.05$ 


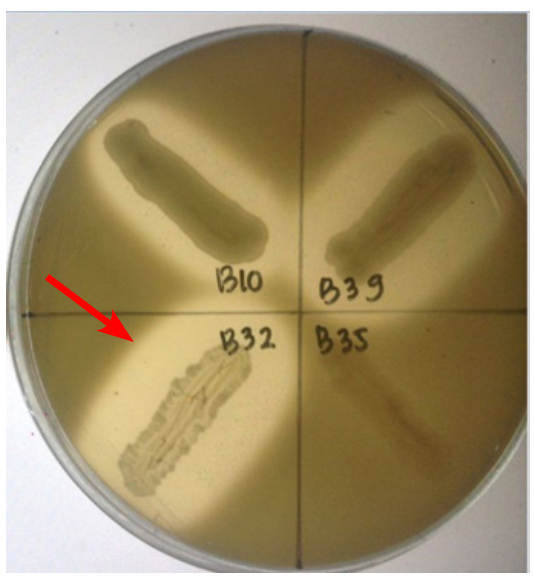

$\mathrm{a}$

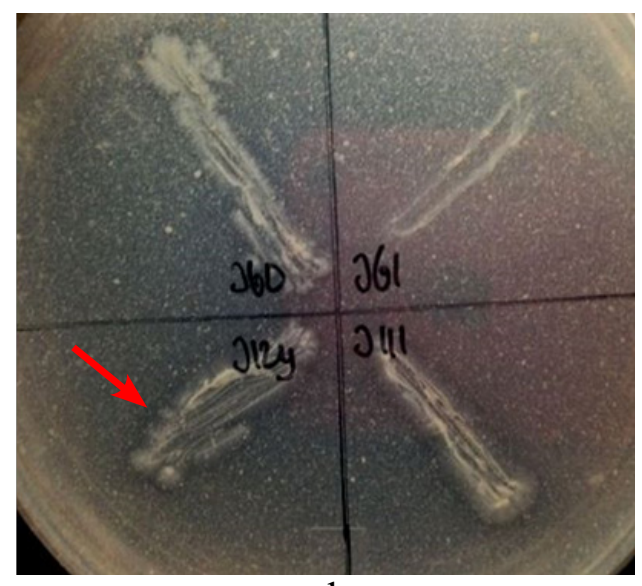

b

Gambar 3 Aktivitas enzim. a, Protease: terbentuknya zona bening pada medium skim milk agar; dan b, Kitinase: terbentuknya zona bening pada medium kitin agar.

Tabel 2 Pengujian aktivitas enzim protease dan kitinase 19 isolat bakteri endofit terpilih

\begin{tabular}{lcc}
\hline & \multicolumn{2}{c}{$\begin{array}{c}\text { Diameter zona bening } \\
(\mathrm{mm})\end{array}$} \\
\cline { 2 - 3 } Perlakuan & Proteolitik & Kitinolitik \\
\hline KAN5-8 & $1.00 \mathrm{ab}$ & $0.00 \mathrm{a}$ \\
KAK2-8 & $0.00 \mathrm{a}$ & $0.00 \mathrm{a}$ \\
KAK2-4 & $2.00 \mathrm{ab}$ & $0.50 \mathrm{~b}$ \\
KAT5-1 & $0.00 \mathrm{a}$ & $0.00 \mathrm{a}$ \\
YRN5-3 & $11.00 \mathrm{e}$ & $2.00 \mathrm{f}$ \\
YRK2-4 & $0.00 \mathrm{a}$ & $0.75 \mathrm{bc}$ \\
YRK5-3 & $4.75 \mathrm{bc}$ & $0.08 \mathrm{a}$ \\
YRT5-10 & $10.50 \mathrm{de}$ & $1.83 \mathrm{ef}$ \\
BAT5-12 & $6.50 \mathrm{~cd}$ & $1.33 \mathrm{~d}$ \\
BAT2-2 & $10.00 \mathrm{de}$ & $0.00 \mathrm{a}$ \\
BAT2-7 & $0.00 \mathrm{a}$ & $0.50 \mathrm{~b}$ \\
BAT-14 & $9.25 \mathrm{de}$ & $1.42 \mathrm{~d}$ \\
BRN2-2 & $0.50 \mathrm{a}$ & $0.00 \mathrm{a}$ \\
BRN5-2 & $9.50 \mathrm{de}$ & $0.00 \mathrm{a}$ \\
BRK5-4 & $1.00 \mathrm{ab}$ & $0.00 \mathrm{a}$ \\
JAT5-1 & $7.50 \mathrm{cde}$ & $1.00 \mathrm{c}$ \\
JAT5-2 & $0.00 \mathrm{a}$ & $0.00 \mathrm{a}$ \\
JRN5-1 & $8.50 \mathrm{cde}$ & $1.58 \mathrm{de}$ \\
JRK5-4 & $9.75 \mathrm{de}$ & $1.33 \mathrm{~d}$ \\
\hline
\end{tabular}

Pengukuran lebar zona bening dilakukan dengan mengukur bagian vertikal dan horizontal dari zona yang terbentuk kemudian direrata. Angka selajur yang diikuti huruf yang sama menunjukkan tidak berbeda nyata menurut uji Duncan pada $\alpha 0.05$

\section{PEMBAHASAN}

Tumbuhan memiliki interaksi dengan mikrob di antaranya dengan bakteri endofit. Bakteri endofit dapat hidup dalam jaringan tumbuhan mulai dari akar, batang dan daun. Akar adalah bagian yang paling banyak di kolonisasi oleh bakteri endofit, yakni sebesar $10^{-5}$ cfu $\mathrm{g}^{-1}$ dibandingkan dengan batang $10^{-4}$ cfu g-1 dan daun $10^{-3} \mathrm{cfu} \mathrm{g}^{-1}$, karena umumnya bakteri endofit berasal dari daerah rizosfer ( Hallmann et al. 1997).

Kemampuan bakteri dalam mendegradasi sel darah merah dibagi menjadi tiga kategori yaitu, beta hemolisis $(\beta)$, alfa hemolisis $(\alpha)$ dan gama hemolisis $(\gamma)$. Beta hemolisis 
mampu mendegradasi komponen sel darah merah sehingga terbentuk zona bening di sekitar koloni bakteri. Alfa hemolisis terjadi ketika sel darah merah berkurang di sekitar koloni dan membentuk warna kehijauan atau kecokelatan di medium. Gama hemolisis tidak menyebabkan reaksi lisis dan perubahan warna pada medium agar darah (Nataliya et al. 2006). Bakteri yang menunjukan sifat $\beta$ dan $\alpha$ hemolisis tidak digunakan pada uji berikutnya karena mampu mendegradasi komponen sel darah manusia (Duncan et al. 2007).

Fahy dan Hayward (1983) menyatakan reaksi hipersensitif dipicu oleh patogen yang memiliki gen Avr. Lesio lokal akan terjadi sebagai reaksi hipersensitif apabila tanaman uji memiliki gen $\mathrm{R}$ yang akan mengenali gen Avr dari bakteri patogen. Gejala lesio lokal merupakan respons tanaman terhadap keberadaan patogen untuk menghambat penyebaran mikroorganisme patogen di dalam jaringan tanaman. Sementara itu, mikrorganisme non patogen tidak membentuk lesio lokal di dalam jaringan. Invasi mikroorganisme dalam jaringan tanaman akan meningkatkan permeabilitas sel tanaman yang kemudian diikuti dengan pengeringan dan kematian jaringan tanaman (Zhu et al. 2000).

Zona bening yang terbentuk pada pengujian kultur ganda merupakan efek dari metabolit sekunder yang dikeluarkan oleh bakteri ke lingkungan berupa antibiotik. Hal ini merupakan salah satu mekanisme pengendalian penyakit oleh agens hayati (Monteiro et al. 2013).

Menurut Nawangsih (2007) agens hayati mampu menghasilkan beberapa senyawa antibiotik seperti amonia, butirolakton, 2,4-diasetilfloroglusinol, pyuloteroin, oomycin, phenazine-1-carboxylic acid, dan 2,4-difloroglucinol. Pada penelitian ini senyawa yang dihasilkan oleh isolat bakteri endofit belum dapat diidentifikasi lebih lanjut.

Antibiotik yang terbentuk berperan dalam mencegah pembentukan komponen dinding sel bakteri patogen, yaitu peptidoglikan. Pada bakteri Gram positif maupun negatif, peptidoglikan merupakan bagian penting dari dinding sel bakteri yang berperan dalam mengatur kelenturan dan integritas dinding sel bakteri. Tanpa peptidoglikan pembentukan dinding sel bakteri akan terhambat dan dapat menyebabkan sel lisis kemudian diikuti oleh kematian sel (Hoff et al. 2008).

Mortalitas Meloidogyne spp. juvenil 2 yang tinggi dipengaruhi oleh metabolit sekunder yang diproduksi oleh agens hayati. Beberapa metabolit sekunder yang bersifat nematisidal antara lain enzim pendegradasi seperti kitinase, protease, lipase yang dapat mendegradasi penyusun dinding sel dan telur dari Meoidogyne spp., senyawa $\mathrm{HCN}$ yang dapat menganggu sistem pernapasan nematoda dan serangga. Terbentuknya senyawa bersifat racun seperti antibiotik yang diproduksi oleh bakteri antagonis dapat menimbulkan peningkatan mortalitas nematoda (Khan et al. 2004; Devi et al. 2007).

Penelitian ini berhasil mendapatkan 19 isolat bakteri endofit asal tanaman mangrove yang berpotensi sebagai agens pengendali hayati patogen tanaman. Beberapa bakteri diketahui mampu memproduksi senyawa enzim protease dan kitinase. Isolat terbaik yang memiliki kemampuan memiliki anti-bakteri dan nematisidal dalam menekan perkembangan $R$. solanacearum dan Meloidogyne spp. adalah isolat BAT2-2 yang di isolasi dari akar mangrove asal Banyuwangi.

\section{UCAPAN TERIMA KASIH}

Ucapan terima kasih disampaikan kepada Southeast Asian Regional Centre for Tropical Biology (SEAMEO BIOTROP), Kementerian Pendidikan dan Kebudayaan Republik Indonesia yang mendanai penelitian ini.

\section{DAFTAR PUSTAKA}

Devi KK, Seth N, Kothamasi S, Kothamasi D. 2007. Hydrogen cyanide-producing rhizobacteria kill subterranean termite Odontotermes obesus (Rambur) by cyanide poisoning under in vitro conditions. Curr Microbiol. 54(1):74-78. DOI: https://doi. org/10.1007/s00284-006-0473-z. 
Duncan S, Louis P, Flint H. 2007. Cultivable bacterial diversity from the human colon. Lett Appl Microbiol. 44(4):343-350. DOI: https://doi.org/10.1111/j.1472765X.2007.02129.x.

Fahy P C, Hayward AC. 1983. Media and methods for isolation and diagnostic test. Di dalam: Plant Bacterial Disease and Diagnostic Guide. New York (US): Academic Pr.

Gayathri P, Muralikrishnan V. 2013. Isolation and characterization of endophytic actinomycetes from mangrove plant for antimicrobial activity. Int J Cur Microbiol App Sci. 2(11):78-89.

Hallmann J, Quadt-Hallmann A, Mahaffee W, Kloepper J. 1997. Bacterial endophytes in agricultural crops. Can J Microbiol. 43(10):895-914. DOI: https://doi. org/10.1139/m97-131.

Hoff B, Pöggeler S, Kück U. 2008. Eighty years after its discovery, Fleming's Penicillium strain discloses the secret of its sex. Eukar Cell. 7(3):465-470. DOI: https://doi.org/10.1128/ec.00430-07.

[Kementan] Kementrian Pertanian. 2015. Produksi dan Produktivitas Tanaman Tomat. http://aplikasi.pertanian.go.id/ bdsp/hasil_lok.asp. [diakses 5 Februari 2016].

Khan A, Williams KL, Nevalainen HK. 2004. Effects of Paecilomyces lilacinus protease and chitinase on the eggshell structures and hatching of Meloidogyne javanica juveniles. Biol Control. 31(3):346352. DOI: https://doi.org/10.1016/j. biocontrol.2004.07.011.
Monteiro FP, Ferreira LC, Pacheco LP, Souza PE. 2013. Antagonism of Bacillus subtilis against Sclerotinia sclerotiorum on Lactuca sativa. J Agric Sci. 5(4):214223. DOI: https://doi.org/10.5539/jas. v5n4p214.

Nataliya V, Balashova, Juan A, Crosby, Lourdes Al Ghofaily, Scott C. 2006. Leukotoxin confers beta-hemolytic activity to Actinobacillus actinomycetemcomitans. Infect Immun. 74(4):2015-2021. DOI: https://doi.org/10.1128/IAI.74.4.20152021.2006.

Nawangsih AA. 2007. Pemanfaatan bakteri endofit pada pisang untuk mengendalikan penyakit darah: isolasi, uji penghambatan in vitro dan in planta. J Pertan Ind. 12(1):43-49.

Ramesh R, Joshi A, Ghanekar M. 2009. Pseudomonads: major antagonistic endophytic bacteria to suppress bacterial wilt pathogen, Ralstonia solanacearum in the eggplant (Solanum melongena L.). World J Microbiol Biotechnol. 25(1):4755. DOI: https://doi.org/10.1007/s11274008-9859-3.

Sudana M, Lotrini M. 2005. Pengendalian terpadu penyakit layu (Ralstonia solanacearum Smith) dan nematoda puru akar (Meloidogyne spp.) pada tanaman jahe gajah. J HPT Tropika. 5(2): 97-103.

Zhu W, MaGbanua MM, White FF. 2000. Identification of two novel hrpassociated genes in the hrp gene cluster of Xanthomonas oryzae pv. oryzae. J Bacteriol. 182(7):1844-1853. DOI: https:// doi.org/10.1128/jb.182.7.1844-1853.2000. 